\title{
Combination therapy with cilostazol, aripiprazole, and donepezil protects neuronal cells from $\beta$-amyloid neurotoxicity through synergistically enhanced SIRT1 expression
}

\author{
Hye Jin Heo ${ }^{1,2}$, So Youn Park ${ }^{1,2}$, Yi Sle Lee ${ }^{1,2}$, Hwa Kyoung Shin ${ }^{3}$, Ki Whan Hong ${ }^{2}$, and Chi Dae Kim ${ }^{1,2, *}$ \\ ${ }^{1}$ Department of Pharmacology, Pusan National University School of Medicine, ${ }^{2}$ Gene \& Cell Therapy Research Center for Vessel-associated Diseases, Pusan \\ National University, ${ }^{3}$ Department of Korean Medical Science, Pusan National University School of Korean Medicine, Yangsan 50612, Korea
}

\section{ARTICLE INFO \\ Received December 20, 2019 \\ Revised March 12, 2020 \\ Accepted March 23, 2020 \\ *Correspondence \\ Chi Dae Kim \\ E-mail: chidkim@pusan.ac.kr}

Key Words

Alzheimer's disease

Aripiprazole

$\beta$-amyloid

Cilostazol

Donepezil
ABSTRACT Alzheimer's disease (AD) is a multi-faceted neurodegenerative disease. Thus, current therapeutic strategies require multitarget-drug combinations to treat or prevent the disease. At the present time, single drugs have proven to be inadequate in terms of addressing the multifactorial pathology of $A D$, and multitarget-directed drug design has not been successful. Based on these points of views, it is judged that combinatorial drug therapies that target several pathogenic factors may offer more attractive therapeutic options. Thus, we explored that the combination therapy with lower doses of cilostazol and aripiprazole with add-on donepezil (CAD) might have potential in the pathogenesis of AD. In the present study, we found the superior efficacies of donepezil add-on with combinatorial mixture of cilostazol plus aripiprazole in modulation of expression of AD-relevant genes: A $\beta$ accumulation, GSK-3 $\beta$, P300, acetylated tau, phosphorylated-tau levels, and activation of $\alpha$-secretase/ADAM 10 through SIRT1 activation in the N2a Swe cells expressing human APP Swedish mutation (N2a Swe cells). We also assessed that CAD synergistically raised acetylcholine release and choline acetyltransferase (CHAT) expression that were declined by increased $\beta$-amyloid level in the activated N2a Swe cells. Consequently, CAD treatment synergistically increased neurite elongation and improved cell viability through activations of PI3K, BDNF, $\beta$-catenin and $\alpha 7$-nicotinic cholinergic receptors in neuronal cells in the presence of $A \beta_{1-42}$. This work endorses the possibility for efficient treatment of $A D$ by supporting the synergistic therapeutic potential of donepezil add-on therapy in combination with lower doses of cilostazol and aripiprazole.

\section{INTRODUCTION}

Alzheimer's disease (AD) is pathologically characterized by the involvement of extracellular deposition of plaques comprised of $\mathrm{A} \beta$ peptide, and intracellular neurofibrillary tangles (NFT), which lead to neurological damages and cognition/memory deficits [1]. The amyloid hypothesis has been considered as the main pathogenesis of AD for two decades. Due to this reason, some of the earliest proposed therapeutic strategies have targeted the elimination of $A \beta$ peptides and deposits.

Cleavage of APP by BACE1 ( $\beta$-site APP cleaving enzyme) generates a membrane-bound soluble $\mathrm{C}$-terminal fragment, and subsequent cleavage by $\gamma$-secretase further produces $A \beta_{1-40}$ and $A \beta_{1-42}$ in brain [2]. Otherwise, the activation of $\alpha$-secretase cleaves APP in its extracellular domain and releases a large soluble $\mathrm{N}$-terminal ectodomain, $\operatorname{sAPP} \alpha$, which reduces $\mathrm{A} \beta$ peptide production [3]. $\alpha$-Cleavage is of pharmacological interest because secreted sAPP $\alpha$ was approved neuroprotective in AD models [4].
This is an Open Access article distributed under the terms of the Creative Commons Attribution Non-Commercial License, which permits unrestricted non-commercial use, distribution, and reproduction in any medium, provided the original work is properly cited. Copyright (c) Korean J Physiol Pharmacol, pISSN 1226-4512, elSSN 2093-3827
Author contributions: K.W.H. and H.K.S. designed the study. H.J.H. and Y.S.L. performed the experiments. S.Y.P. and C.D.K. analyzed the data. H.K.S. and K.W.H. wrote the manuscript. C.D.K., corresponding author. All authors contributed to and approved the final manuscript. 
GSK-3 $\beta$ is activated by $A \beta$ peptides [5] and increased GSK-3 $\beta$ activity accounts for the abnormal tau hyperphosphorylation, and the accumulation of aberrantly phosphorylated tau, which underlies tau-mediated neurodegeneration [6,7]. Inhibition of GSK$3 \beta$ reduces the production of $A \beta$ peptides in amyloid plaques [8]. Interestingly, cilostazol increased GSK-3 $\beta$ phosphorylation at Ser 9 (inactive form) and $\beta$-catenin phosphorylation at Ser675 in cytosol and nuclei and thereby, suppressed $\mathrm{A} \beta_{1-40}$-induced neurotoxicity and enhanced neurite elongation [9]. Evidence has accumulated that alterations in nerve-growth factor (NGF)/TrkA signaling cause selective degeneration of cholinergic basal forebrain neurons in $\mathrm{AD}[10,11]$. Based on these evidences, cholinergic hypothesis was postulated that cholinotropic agents can be a logical choice for preventative therapy in $\mathrm{AD}[12,13]$.

In recent years, the role of sirtuins in $\mathrm{AD}$ has become increasingly apparent [14-16]. Julien et al. [17] have emphasized a close relationship between decrease in SIRT1 levels and tau accumulation in $\mathrm{AD}$ and $\mathrm{A} \beta$ accumulation in the brains of patients with AD. It has been demonstrated that SIRT1 activates transcriptions of gene encoding $\alpha$-secretase/ADAM10 (a disintegrin and metalloproteinase 10) via the deacetylation of retinoic acid receptor- $\beta$ (RAR $\beta)[15,18]$. Cilostazol was reported to suppress accumulations of full-length APP and A $\beta$ by activating ADAM10 via upregulating SIRT1-coupled RAR $\beta$ activation [19]. In line with these, it has been reported increased CREB (cAMP-response element binding protein) phosphorylation by cilostazol is associated with elevated levels of phosphorylated CK2, Akt, and Bcl-2 with reduced caspase-3 activity in the penumbral region of focal ischemic rat brain [20,21]. Park et al. [22] found cilostazol reduced intracellular $A \beta$ levels and phosphorylated tau levels in activated neuro2A (N2a) Swe cells, and significantly improved spatial learning and memory in the $A \beta$-injected mice.

On the other hand, aripiprazole as an atypical antipsychotic with partial agonistic activity, acts on dopamine $\mathrm{D}_{2}$ and $5-\mathrm{HT}_{1 \mathrm{~A}}$ receptors, and has a potent partial agonistic effect on $5-\mathrm{HT}_{1 \mathrm{~A}}$ receptors and an antagonistic effect on $5-\mathrm{HT}_{2 \mathrm{~A}}$ receptors [23]. Aripiprazole was licensed by the Food and Drug Administration (FDA) and European Medicine Agency (EMA) for treatment of schizophrenia [24] and major depression [25]. Declining of cognitive function in $\mathrm{AD}$ patients is prevalently accompanied by psychotic symptoms and behavior [26,27]. De Deyn et al. [28] reported that aripiprazole-treatment showed significant improvements in psychiatric rating scale vs. placebo treatment in $\mathrm{AD}$ patients with psychosis. Recently, Park et al. [29] reported aripiprazole ameliorates $A \beta_{1-42}$-evoked toxicity associated with increased neurite outgrowth and viability in neuronal cells.

At present time, only five prescription drugs are approved by the US FDA for the symptomatic treatment of AD [30]. These are: (i) donepezil, (ii) galantamine, (iii) memantine (a non-competitive $\mathrm{N}$-methyl-D-aspartate [NMDA] receptor antagonist.), (iv) rivastigmine, and (iv) donepezil and memantine. $\mathrm{AD}$ is associated with neurodegenerative changes associated with depletion of
nAChRs and loss of cholinergic neurons, thereby resulting in progressive cognitive and functional deficits clinically [31,32]. Donepezil ( $R, S$-1-benzyl-4-[(5,6-dimethoxy-1-indanon)-2-yl] methylpiperidine hydrochloride) (E2020), a potent and reversible acetylcholinesterase (AChE) inhibitor, has been reported to show moderate improvement of cognitive function with minimal side effects [33] and early prescribed for treatment of cognitive dysfunction in $\mathrm{AD}$ [34].

Since the pathogenesis of AD is known to be multifactorial, and current single drug-based strategies have been proven to be inadequate, in this study we proposed an alternative therapeutic approach: a multitarget-directed drug combination including cilostazol plus aripiprazole with donepezil add-on for modulation of A $\beta$ accumulation, phosphorylated-tau, GSK-3 $\beta, \alpha$-secretase/ ADAM10, and SIRT1 levels in N2a Swe cells and for revitalization of acetylcholine $(\mathrm{ACh})$ release and choline acetyltransferase (CHAT) expression.

\section{METHODS}

\section{Experimental groups in vitro study}

Group 1: N2a cells [control].

Group 2: N2a Swe cells activated by culturing in 1\% FBScontaining medium for $24 \mathrm{~h}$ [vehicle].

Group 3: After pretreatment with cilostazol $(3 \mu \mathrm{M})$ /aripiprazole $(3 \mu \mathrm{M}), \mathrm{N} 2 \mathrm{a}$ Swe cells were activated [CA group].

Group 4: After pretreatment with cilostazol/aripiprazole + donepezil (DNP; $3 \mu \mathrm{M})$, N2a Swe cells were activated [CAD group].

Group 5: N2a Swe cells pretreated with donepezil $(3 \mu \mathrm{M})$ and then activated [DNP group].

\section{Cell culture}

Mouse neuroblastoma N2a and N2a Swe mutant cells, were cultured in Dulbecco's modified Eagle's medium (DMEM) containing 10\% fetal bovine serum (FBS; Gibco, Grand Island, NY, USA) at $37^{\circ} \mathrm{C}$ in a $5 \% \mathrm{CO}_{2} / 95 \%$ air. For evoking endogenous $\mathrm{A} \beta$ overproduction, the culture medium was switched from medium containing $10 \% \mathrm{FBS}$ to medium with $1 \% \mathrm{FBS}$, and then cultured for 3, 12, 24, or $48 \mathrm{~h}$ as described by Lee et al. [35]. When drug treatment was required, cells were previously treated for $3 \mathrm{~h}$ and then exposed to medium containing 1\% FBS. HT22 cells were also maintained in Dulbecco's modified Eagle's medium (DMEM) containing $10 \%$ FBS.

\section{Western blotting}

Following stimulation with drugs or inhibitors, N2a Swe mutant cells were scraped and lysed in lysis buffer [35]. After centrifugation at 13,000 rpm for $7 \mathrm{~min}, 30 \mu \mathrm{g}$ of total protein was loaded 
onto 10\% SDS-polyacrylamide gels. Subsequently, separated proteins were transferred to nitrocellulose membranes. Membrane was blocked with $5 \%$ skim milk (at $4^{\circ} \mathrm{C}$ overnight) and incubated with antibodies against anti-A $\beta$ (6E10) and SIRT1 (Covance, Emeryville, CA, USA) (1:500 dilution), GSK-3 $\beta$, GSK-3 $\beta$ phosphorylated at Ser9 (GSK-3 $\beta$ P-Ser9), anti-p-Tau (p-Ser396; SigmaAldrich, St. Louis, MO, USA), and anti-ac-Tau (Acetyl lys174; Signalway Antibody, College Park, MD, USA). Antibody against P300, ADAM10 and GSK-3 $\beta$ phosphorylated at Tyr216 (1:500 dilution) were from Santa Cruz Biotechnology (Santa Cruz, CA, USA), and anti-p-CREB Serl33 was from Cell Signaling Technology, Danvers, MA, USA. Membranes were probed with an anti$\beta$-actin antibody (MP Biomedicals, LLC, Solon, OH, USA) as an internal control. DMSO was used as vehicle $(<0.1 \% \mathrm{v} / \mathrm{v}$ of final volume).

\section{Assay of $\alpha$-secretase activity}

As described by Lee et al. [19], N2a Swe cells were cultured in DMEM supplemented with $10 \%$ FBS. $\alpha$-Secretase activities were analyzed in cultured cell lysates using a kit (No. AS-72085) Fluorimetric; ANASpec, Fremont, CA, USA). Cell membranes were homogenized in assay buffer containing $0.1 \%(\mathrm{v} / \mathrm{v})$ Triton X-100. After addition $50 \mu \mathrm{l}$ of stop solution to each well, fluorescence intensities were determined at excitation and emission wavelengths 490 and $520 \mathrm{~nm}$, respectively. The assay was assayed three times in duplicate.

\section{Measurement of cholinergic function markers}

CHAT expression: Cultured N2a and N2a Swe cells were homogenized in 9 volumes of cold saline and centrifuged at 3,000x $\mathrm{g}$ to obtain supernatants, and these were diluted with a buffer solution. Protein concentrations of the supernatants were measured by Coomassie blue method. Anti-CHAT (1:500 dilution) was from Millipore (Temecula, CA, USA). CHAT expressions were assessed by Western blotting.

Acetylcholine assay: N2a Swe cells were destroyed by repeated freezing and thawing to release intracellular components. The supernatants were collected carefully after centrifuging for $20 \mathrm{~min}$ at 2,000 rpm. Intracellular acetylcholine levels were measured by using a commercially available ELISA kit. (Acetylcholine ELISA Kit; Biovision, Milpitas, CA, USA). Absorbances were measured at O.D. $450 \mathrm{~nm}$.

\section{Neurite elongation}

For determination of neurite elongation, HT22 cells instead of N2a cells were cultured in the six-well culture plate at a density of 1,000 cells per $\mathrm{cm}^{2}$ on the cover slips [29]. HT22 cells were incubated with $A \beta_{1-42}(3 \mu \mathrm{M})$ alone or with donepezil, $\mathrm{CA}$ and $\mathrm{CAD}$ for 5 days. For the analysis, cells were fixed in the parafor- maldehyde (4\%) and then incubated with SMI-312 antibody (Cat. No. SMI312R; Covance, Princeton, NJ, USA) for $1 \mathrm{~h}$. Secondary antibody conjugated to Alexa Fluor 488 (Invitrogen, Carlsbad, CA, USA) was applied for $1 \mathrm{~h}$. Fluorescent images were magnified at $\times 400$ using an Axiovert 200 fluorescence microscope (Carl Zeiss, Jena, Germany). K252A was from Calbiochem (San Diego, CA, USA) and imatinib was from Toronto Research Chemicals (Toronto, ON, Canada). Methyllycaconitine citrate was purchased from Research Biochemicals International, Natick, MA and LY294002, was from Calbiochem, Darmstadt, Germany.

\section{Cell viability}

Cell viability was evaluated by a modified MTT [3-(4,5-dimethylthiazol-2-yl)-2,5-diphenyltetrazolium bromide, SigmaAldrich] reduction assay. Cells were pretreated with drugs for $3 \mathrm{~h}$ before adding $\mathrm{A} \beta_{1-42}(10 \mu \mathrm{M}$ ). Then, $10 \mu \mathrm{l}$ of MTT (at $5 \mathrm{mg} / \mathrm{ml}$ in phosphate-buffered saline was included to each well $(500 \mu \mathrm{g} / \mathrm{ml})$ for $3 \mathrm{~h}$. Optical densities were measured at a wavelength $570 \mathrm{~nm}$ (reference wavelength $630 \mathrm{~nm}$ ) using enzyme-linked immunosorbent assay (Bio-Tek Instruments, Burlington, VT, USA).

\section{Statistical analyses}

Results were expressed as means \pm standard error of the mean. The significances of differences between control and drug treatment groups were analyzed by ANOVA followed by Tukey's multiple comparison test. The Student's t-test was used to determine the significances of differences between untreated cells and cells treated with inhibitors. $\mathrm{p}<0.05$ was judged statistically significant.

\section{RESULTS}

Time-dependent increases in amyloid- $\beta$ peptide with P-tau, Ac-tau, P300 and GSK-3 $\beta$ P-Tyr-216 levels in the activated N2a Swe cells

We assayed time-dependent increases in $A \beta$, phosphorylated tau (P-tau), acetyl tau (Ac-tau), P300, and GSK-3 $\beta$ P-Tyr-216 expression levels by ELISA in the activated N2a Swe cells. To induce $\mathrm{A} \beta$ overproduction, culture medium was switched from medium containing $10 \%$ FBS to medium with $1 \% \mathrm{FBS}$, and neuronal cells were cultured for 3, 12, 24, and $48 \mathrm{~h}$. As shown in Fig. 1A, N2a cells showed little $A \beta$ density before or at $24-48 \mathrm{~h}$ after FBS depletion. A $\beta$ levels (assayed by ELISA) were also low in N2a cells after culture for $24-48 \mathrm{~h}$ in FBS depleted medium. However, in the activated $\mathrm{N} 2 \mathrm{a}$ Swe cells $\mathrm{A} \beta$ concentrations increased time-dependently $(3,12,24$, and $48 \mathrm{~h})$, and the higher concentration was observed from $24 \mathrm{~h}(591 \pm 24.9 \%)$ (Fig. 1A). In addition, Western blotting for P-tau $\left(\mathrm{F}_{6,20}=8.483, \mathrm{p}=0.0005\right)$, Ac-tau $\left(\mathrm{F}_{6,20}=9.19\right.$, 

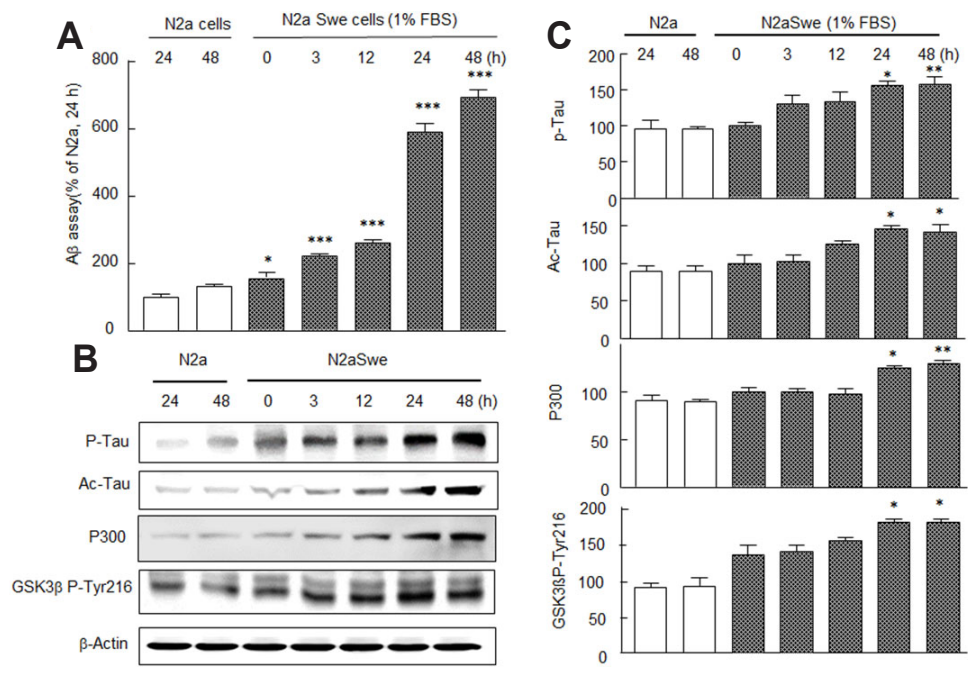

Fig. 1. Time-dependent increases in $\mathbf{A} \beta$ production and phosphorylation. (A) Time-dependent increases in $A \beta$ production in mouse neuroblastoma neuro2A (N2a) Swe cells as determined by ELISA, represented as percentages of N2a cells cultured for $24 \mathrm{~h}$ as $100 \%$. (B) Time-dependent increases in A $\beta$ phosphorylated Tau (P-tau), acetylated tau (Ac-tau), P300, and GSK-3 $\beta$ P-Tyr-216 levels as determined by Western blot. Cells were cultured in $1 \%$ FBS for 3, 12, 24, or $48 \mathrm{~h}$, respectively. (C) Quantitative results are expressed as the mean percentages \pm SEMs with respect to N2a cells cultured for 24 $\mathrm{h}($ control $=100 \%)$ from five experiments. ${ }^{*} p<0.05,{ }^{* *} p<0.01 ;{ }^{* * *} p<0.001$ vs. N2a controls.
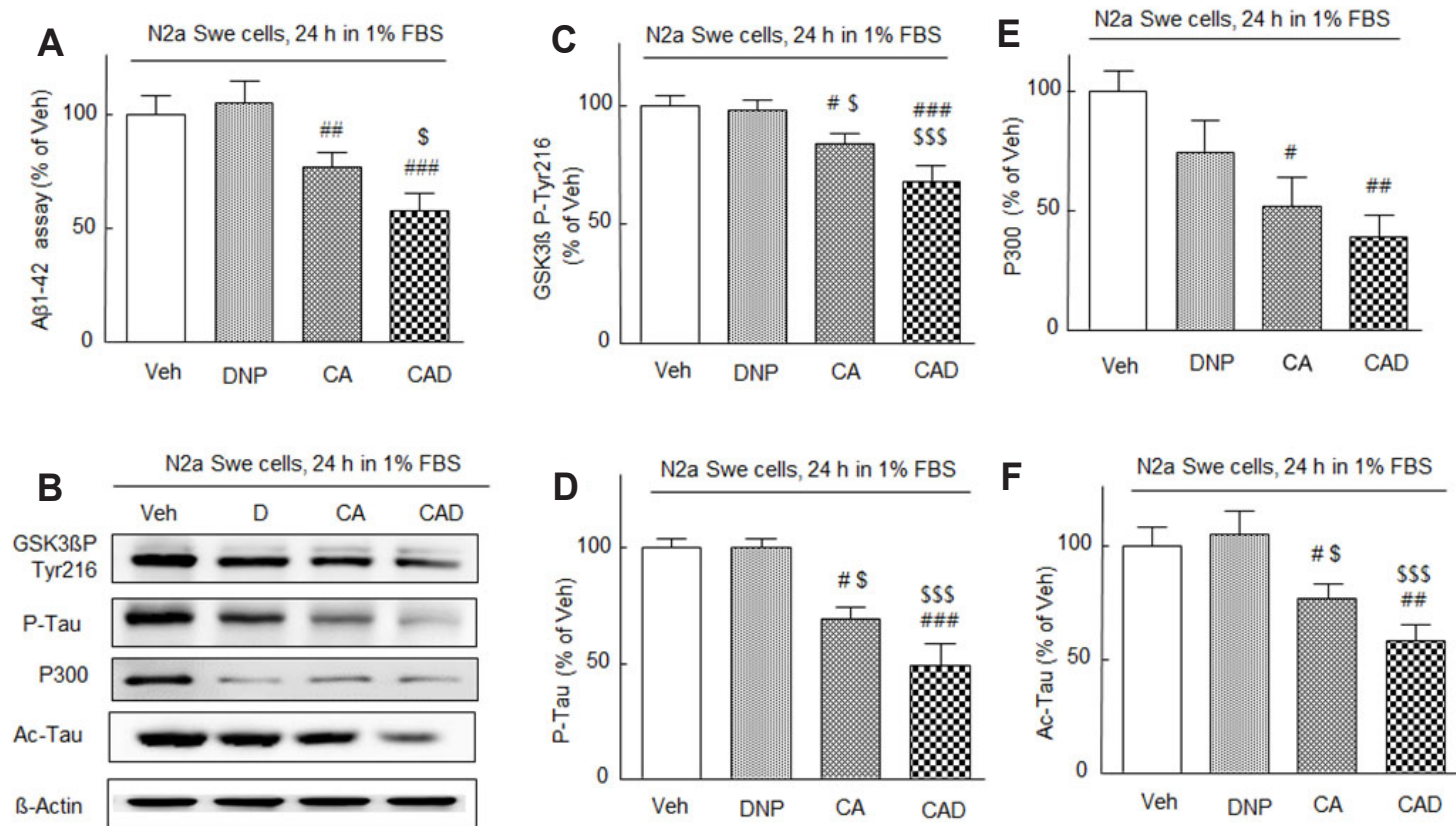

Fig. 2. Effects of donepezil (DNP), cilostazol + aripiprazole (CA), and CA + DNP (CAD). (A) Suppressive effects of $3 \mu M$ donepezil (DNP), $3 \mu M$ cilostazol $+3 \mu \mathrm{M}$ aripiprazole (CA), and CA $+3 \mu \mathrm{M}$ DNP (CAD) on A $\beta$ production in neuro2A (N2a) Swe cells as determined by ELISA, are represented as percentages of N2a cells cultured for $24 \mathrm{~h}$. (B) Representative Western blots of GSK-3 $\beta$ P-Tyr-216, phosphorylated tau (P-tau), P300, and acetylated tau (Ac-tau) expression levels in activated N2a Swe cells cultured for $24 \mathrm{~h}$. Quantitative analysis of GSK-3ß P-Tyr 216 (C), P-tau (D), P300 (E), and Ac-tau expression levels (F). Results are expressed as the means \pm SEMs of percentages of vehicle values (100\%) of activated N2a Swe cells from four experiments. $" \mathrm{p}<0.05, \# \mathrm{p}<0.01, \# \mathrm{p} p 0.001$ vs. vehicle (veh); ${ }^{\$} \mathrm{p}<0.05,{ }^{\$ \$ \$} \mathrm{p}<0.001$ vs. DNP.

$\mathrm{p}=0.0003), \mathrm{P} 300\left(\mathrm{~F}_{6,20}=10.99, \mathrm{p}=0.0001\right)$, and GSK-3 $\beta$ Tyr216 $\left(\mathrm{F}_{6,20}=12.49, \mathrm{p}=0.0001\right)$ also showed time-dependent increases that paralleled those of $A \beta$ levels (Fig. 1B).
Inhibition of increased A $\beta$, P-tau, Ac-tau, P300, and GSK-3 $\beta$ P-Tyr-216 levels in activated N2a Swe cells by CAD

It was aimed to evaluate whether the three-drug combination 
(CAD) therapy could synergistically suppress endogenously accumulated A $\beta$ level in activated N2a Swe cells. As observed in the previous reports $[29,35]$, minimum concentrations of $3 \mu \mathrm{M}$ of cilostazol and $3 \mu \mathrm{M}$ of aripiprazole were applied in combination in this study. N2a Swe cells were pretreated with drugs $3 \mathrm{~h}$ prior to exposure to $1 \%$ FBS medium and then cultured for further 24 h. A $\beta$ accumulation was not suppressed by $3 \mu \mathrm{M}$ DNP alone but was significantly suppressed by CA (cilostazol $3 \mu \mathrm{M}+$ aripiprazole $3 \mu \mathrm{M}, \mathrm{p}<0.01)$ and further suppressed by CAD (CA + DNP) $(\mathrm{p}<0.001)$. CAD more strongly suppressed $\mathrm{A} \beta$ accumulation (to $55.0 \pm 6.5 \%, \mathrm{p}<0.05$ ) than $\mathrm{CA}$ (to $65.0 \pm 3.9 \%$ ), indicating that $\mathrm{A} \beta$ accumulation was more efficiently decreased by treatment with CAD (Fig. 2A).

It has been reported that phosphorylation of GSK-3 $\beta$ at Tyr 216 increases GSK-3 $\beta$ activity in neuronal cells and in the ischemic cortical neurons [36]. Furthermore, active GSK-3 $\beta$ increased hyperphosphorylation of tau [37]. Based on these reports, we examined whether CAD therapy could synergistically suppress GSK$3 \beta$ P-Tyr-216, P-tau, P300, and Ac-tau expression in parallel with reduced $\mathrm{A} \beta$ level (Fig. $2 \mathrm{~B}$ ).

FBS-depleted medium-induced increased GSK-3 $\beta$ Tyr216 was not inhibited by DNP, but both CA and CAD treatment significantly suppressed this increase to $73 \pm 12.3 \%(\mathrm{p}<0.05)$ by CA and to $54 \pm 10.0 \%(\mathrm{p}<0.001)$ by $\mathrm{CAD}$, respectively $\left(\mathrm{F}_{3,15}=16.9\right.$, $\mathrm{p}=0.0001$ ). Similarly, P-tau expression were also not affected by DNP but were significantly suppressed by CA $(69 \pm 5.6 \%$, p < 0.05 vs. vehicle) and $\mathrm{CAD}(49.0 \pm 9.5 \%, \mathrm{p}<0.001)\left(\mathrm{F}_{3,15}=15.9, \mathrm{p}=\right.$ 0.0002) (Fig. 2C, D).

$\mathrm{A} \beta$ aggregates have been reported to activate $\mathrm{p} 300$ (protein of $300 \mathrm{kDa}$ ), and tau is acetylated by histone acetyltransferase in an intracellular $\mathrm{A} \beta$ accumulation-dependent manner [38]. Recently, it was reported that acetylated tau inhibits its degradation and enhances tau aggregation [39]. P300 expressional increases in N2a Swe cells after $24 \mathrm{~h}$ in depleted medium were not inhibited by DNP, but were significantly inhibited by CA $(52 \pm 12.0 \%, \mathrm{p}<0.05$ vs. vehicle $)$ and $\operatorname{CAD}(39 \pm 9.6 \%, \mathrm{p}<0.01)\left(\mathrm{F}_{3,15}=5.697, \mathrm{p}=0.0116\right)$ (Fig. 2E, F), and changes in Ac-tau levels displayed a similar pattern $\left(\mathrm{F}_{3,15}=14.66, \mathrm{p}=0.0003\right)$. These results indicate that CAD treatment synergistically inhibited the expressions of several neurodegenerative pathological factors which were induced by endogenous $A \beta$ accumulation.

\section{Time-dependent decrease in ADAM10 expression in N2a Swe cells in FBS-depleted medium and synergistic upregulation of ADAM10 by CAD}

Postina et al. [3] reported that neuronal overexpression of ADAM10 augments the $\alpha$-secretase cleavage of APP and its activation inhibits $A \beta$ peptide production via APP cleavage. Lee et al. [19] have shown that cilostazol attenuates $A \beta$ production by increasing ADAM10/ $\alpha$-secretase activity via SIRT1-coupled RAR $\beta$ activation in N2a Swe cells. As shown in Fig. 3A, ADAM10 expression significantly decreased in N2a Swe cells in FBS-depleted medium in a time $(0,3,12$, and $24 \mathrm{~h})$-dependent manner $\left(\mathrm{F}_{5,23}=14.60\right.$, $\mathrm{p}<0.0001$ ), while it remained unchanged in N2a cells. Moreover, ADAM10 expression after $24 \mathrm{~h}$ in depleted FBS medium $(28.3 \pm$ $4.3 \%$ of the $\mathrm{N} 2 \mathrm{a}$ cells, control $=100 \%$ ) was increased by CA pretreatment to $220 \pm 20.8 \%$ ( $\mathrm{p}<0.01 \mathrm{vs}$. vehicle) and by CAD to $297 \pm 21.8 \%$ ( $\mathrm{p}<0.001$ vs. activated N2a Swe) $\left(\mathrm{F}_{4,19}=17.7, \mathrm{p}<\right.$ $0.0001)$. The protective effect of CAD was suppressed by $10 \mu \mathrm{M}$ TIMP (an ADAM10 inhibitor, Amour et al. [40]) to $133 \pm 21.1 \%$ ( $\mathrm{p}<0.001$ vs. activated N2a Swe controls) (Fig. 3B).
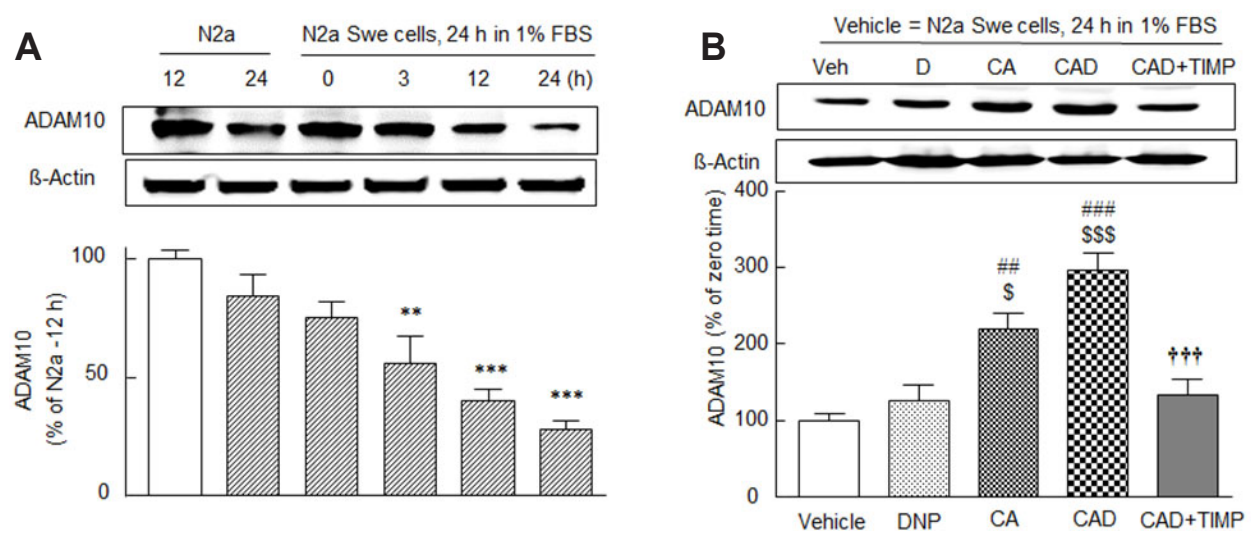

Fig. 3. Decreased ADAM10 expression in the activated neuro2A (N2a) Swe cells and its recovery. (A) Time-dependent decreases in ADAM10 protein levels when N2a Swe cells were cultured in 1\% FBS-containing medium for 3, 12, 24, or $48 \mathrm{~h}$. Means \pm standard error of the mean (SEMs) are expressed as percentages of values of N2a cell cultured for $24 \mathrm{~h}(100 \%)$ from four experiments. ${ }^{* *} \mathrm{p}<0.01 ;{ }^{* * *} \mathrm{p}<0.001 \mathrm{vs}$. values of N2a cells cultured for $24 \mathrm{~h}$. (B) Synergistic upregulation of decreased ADAM10 expression in the N2a Swe cells (at $24 \mathrm{~h}$ after FBS depletion [control] $=100 \%$ ) by $3 \mu \mathrm{M}$ donepezil (DNP), $3 \mu \mathrm{M}$ cilostazol $+3 \mu \mathrm{M}$ aripiprazole (CA) and CA + DNP (CAD). Inhibition of CAD-stimulated ADAM10 expression by $10 \mu M$ TIMP (an ADAM10 inhibitor). Means \pm SEMs are expressed as percentages of vehicle values (100\%) of activated N2a Swe cells from four experiments. "\# $p<0.01$, ${ }_{\# \# \#} \mathrm{p}<0.001$ vs. vehicle (veh); ${ }^{\$} \mathrm{p}<0.05,{ }^{\$ \$ \$} \mathrm{p}<0.001$ vs. DNP; ${ }^{\text {t+t }} \mathrm{p}<0.001$ vs. CAD alone. 


\section{Decrease in $\alpha$-secretase activity in the activated N2a Swe cells and its upregulation by CAD therapy}

We investigated how cilostazol, cilostazol + DNP, cilostazol + aripiprazole, and CAD affect $\alpha$-secretase activity in the activated N2a Swe cells. $\alpha$-Secretase activity was significantly reduced to $55 \pm 4.6 \%$ after $24 \mathrm{~h}$ in depleted medium $(\mathrm{p}<0.001)$. This reduction was significantly prevented by pretreatment with $3 \mu \mathrm{M}(\mathrm{C} 3)$ and $10 \mu \mathrm{M}(\mathrm{C} 10)$ of cilostazol to $99.0 \pm 8.6 \%$ ( $<<0.05)$ and $119.2 \pm 6.0 \%$ ( $p<0.001)$, respectively. $\alpha$-Secretase activity was also significantly elevated by cotreatments with cilostazol $(3 \mu \mathrm{M})$ and DNP $(1,3,10 \mu \mathrm{M})$, or by cotreatments with cilostazol $(3 \mu \mathrm{M})$ and aripiprazole (1, 3, $10 \mu \mathrm{M})$ (Fig. 4A-C).

We also compared the abilities of DNP alone, CA and CAD to upregulate $\alpha$-secretase activity in the activated N2a Swe cells. In this experiment, reduced $\alpha$ - secretase activity $(56.1 \pm 2.7 \%, \mathrm{p}<$ 0.001 ) was synergistically elevated to $181.3 \pm 5.6 \%$ by CAD, which was much higher than those achieved by DNP alone or cilostazol + aripiprazole combination $\left(\mathrm{F}_{7,43}=40.9, \mathrm{p}<0.0001\right)$. This upregulation by CAD was significantly inhibited by pretreatment with Rp-cAMPS $(10 \mu \mathrm{M}$, a cAMP-dependent protein kinase inhibitor) to $77.0 \pm 11.5 \%$ ( $\mathrm{p}<0.001)$, by pretreatment with sirtinol (20 $\mu \mathrm{M}$, SIRT1 inhibitor) [41] to $69.5 \pm 9.2 \%$ ( $\mathrm{p}<0.001)$, and by TIMP $(10 \mu \mathrm{M}$, an ADAM10 inhibitor) [40] to $76.3 \pm 8.5 \%$ (p < 0.001) (Fig. 4D).

\section{CAD treatment synergistically increased SIRT1 protein expression and its activity}

Lee et al. [35] reported that in the activated N2a Swe cells, SIRT1 protein expression was time (3, 12, 24, 48 h)-dependently decreased. In the present study, N2a Swe cells were pretreated with $3 \mu \mathrm{M}$ DNP, CA ( $3 \mu \mathrm{M}$ cilostazol $+3 \mu \mathrm{M}$ aripiprazole), or CAD $(3 \mu \mathrm{M}$ cilostazol $+3 \mu \mathrm{M}$ aripiprazole $+3 \mu \mathrm{M}$ DNP) for 3 $\mathrm{h}$, and then cultured in $1 \%$ FBS medium for $24 \mathrm{~h}$. Results were expressed as percentages of activated N2a Swe controls (vehicle = $100 \%)$. SIRT1 expression was significantly upregulated by CAD to $304.6 \pm 38.2 \%$ ( $\mathrm{p}<0.001$ vs. vehicle; $\mathrm{p}<0.01$ vs. DNP; $\mathrm{p}<0.05$ vs. $\mathrm{CA})$ in a synergistic manner $\left(\mathrm{F}_{4,19}=9.221, \mathrm{p}=0.0006\right)$, whereas it was marginally changed by $3 \mu \mathrm{M}$ DNP and CA ( $3 \mu \mathrm{M}$ cilostazol $+3 \mu \mathrm{M}$ aripiprazole). Furthermore, this effect of CAD was significantly inhibited by $20 \mu \mathrm{M}$ sirtinol ( $\mathrm{p}<0.01$, a SIRT1 inhibitor) (Fig. 5A).

SIRT1 deacetylase activities were significantly reduced to $66 \pm$ $4.5 \%(\mathrm{p}<0.05)$ and this reduction was significantly prevented by CA to $119 \pm 6.1 \%$ ( $p<0.001$ vs. vehicle) and more increased by CAD to $155 \pm 9.0 \%$ ( $p<0.001$ vs. vehicle; $\mathrm{p}<0.001$ vs. DNP; $\mathrm{p}<0.05$ vs. CA) $\left(\mathrm{F}_{5,29}=19.77, \mathrm{p}=0.0039\right)$, and these effects were significantly suppressed by $20 \mu \mathrm{M}$ sirtinol $(\mathrm{p}<0.001)$, indicating that SIRT1 activity was decreased by intracellular $A \beta$, and threedrug combination therapy (CAD) upregulated the reduced SIRT1 protein expression and deacetylase activity in a synergistic manner (Fig. 5B).

Fusco et al. [42] have reported that CREB directly upregulates
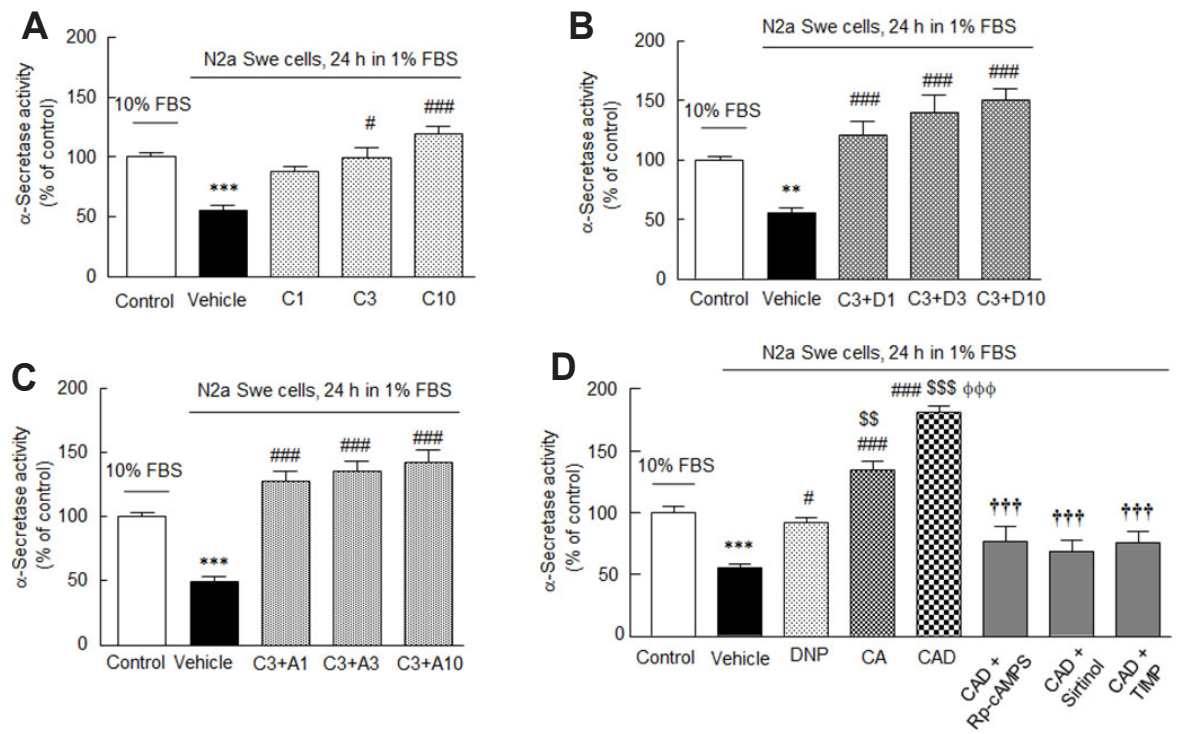

Fig. 4. Significantly decreased $\alpha$-secretase activity at $24 \mathrm{~h}$ after FBS depletion and concentration-dependent recovery by cilostazol. (A), $3 \mu \mathrm{M}$ cilostazol (C3) + 1, 3, $10 \mu \mathrm{M}$ donepezil (D1, D3, D10) (B), $3 \mu \mathrm{M}$ cilostazol (C3) + 1, 3, $10 \mu \mathrm{M}$ aripiprazole (A1, A3, A10) (C). (D) Synergistic upregulation of $\alpha$-secretase activity in the neuro2A (N2a) Swe cells by $3 \mu \mathrm{M}$ donepezil (DNP) alone, $3 \mu \mathrm{M}$ cilostazol $+3 \mu \mathrm{M}$ aripiprazole (CA), CAD, and blocking of CAD-stimulated $\alpha$-secretase activity by $10 \mu \mathrm{M}$ Rp-CAMPS, $20 \mu \mathrm{M}$ sirtinol and $10 \mu \mathrm{M} \mathrm{TIMP}$, respectively. Means \pm SEMs are expressed as percentages of control values (100\%) of N2a cells (with $10 \%$ FBS) from 4-8 experiments. ${ }^{* *} \mathrm{p}<0.01$, ${ }^{* * *} \mathrm{p}<0.001 \mathrm{vs}$. control; ${ }^{\#} \mathrm{p}<0.01$, ${ }^{\# \#} \mathrm{p}<0.001 \mathrm{vs}$. vehicle (veh); ${ }^{\$ \$} p<0.01,{ }^{\$ \$ \$} p<0.001$ vs. DNP; ${ }^{+t \dagger} p<0.001$ vs. CAD alone. ${ }^{\phi \phi \phi} p<0.001$ vs. CA. 


\section{A}

N2aSwe cells, $24 \mathrm{~h}$ in $1 \%$ FBS medium

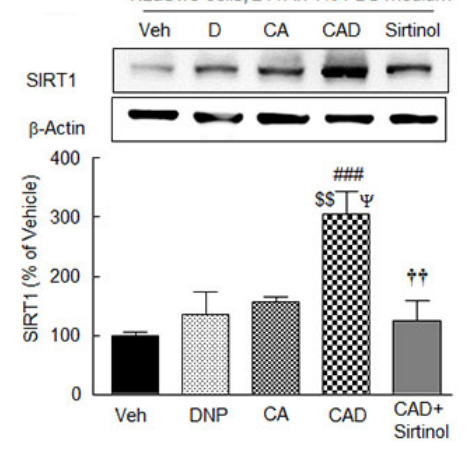

B

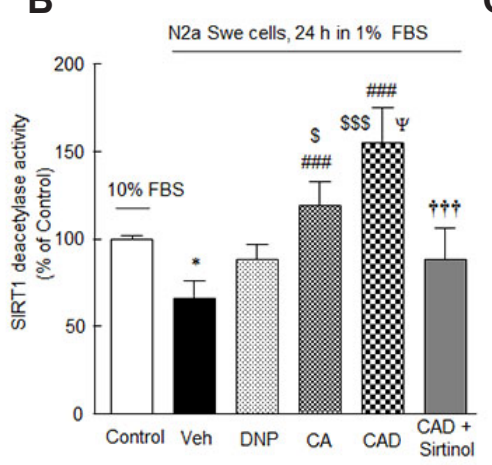

C

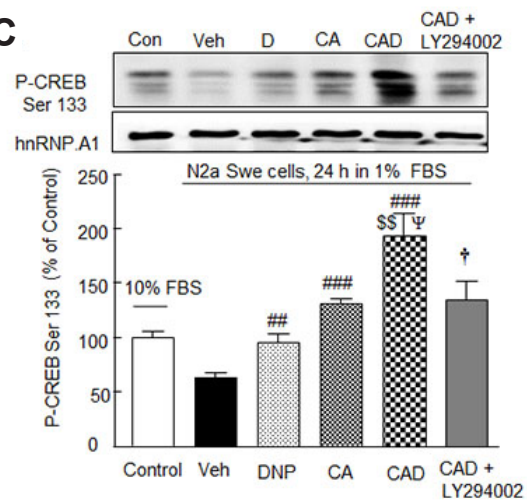

Fig. 5. Drug effects on SIRT1 expression and deacetylase activity in the activated neuro2A (N2a) Swe cells. (A) Upregulation of SIRT1 expression in the N2a Swe cells by $3 \mu \mathrm{M}$ donepezil (DNP), $3 \mu \mathrm{M}$ cilostazol $+3 \mu \mathrm{M}$ aripiprazole (CA) and CA + $3 \mu \mathrm{M}$ DNP (CAD) and blocking of CAD-stimulated SIRT1 expression by $20 \mu \mathrm{M}$ Sirtinol. Means \pm standard error of the mean (SEMs) are expressed as percentages of vehicle $($ veh $=100 \%)$ of activated N2a Swe cells from 5 experiments. (B) Significantly decreased SIRT1 deacetylase activity at $24 \mathrm{~h}$ after $1 \%$ FBS medium and synergistic upregulation over the control level by drugs and blocking of CAD-stimulated SIRT1 expression by $20 \mu \mathrm{M}$ sirtinol. (C) Synergistic upregulation of nuclear P-CREB Ser133 levels by DNP, CA, CAD, and blocking of CAD-stimulated intranuclear P-CREB Ser133 levels by $30 \mu \mathrm{M}$ of LY294002. Means \pm SEMs are expressed as percentages of control (100\%) of N2a Swe cells (10\% FBS) from 4 experiments. ${ }^{*} p<0.05$ vs. control; ${ }^{\# \#} p<0.01,{ }^{\# \#} p<0.001$ vs. vehicle (veh); ${ }^{\$} p<0.05,{ }^{\$ \$} p<$ $0.01,{ }^{\$ \$ \$} \mathrm{p}<0.001$ vs. DNP; ${ }^{\psi} \mathrm{p}<0.05$ vs. $C A ;{ }^{\dagger} \mathrm{p}<0.05,{ }^{+\dagger} p<0.01,{ }^{\dagger+t} p<0.001$ vs. CAD alone.
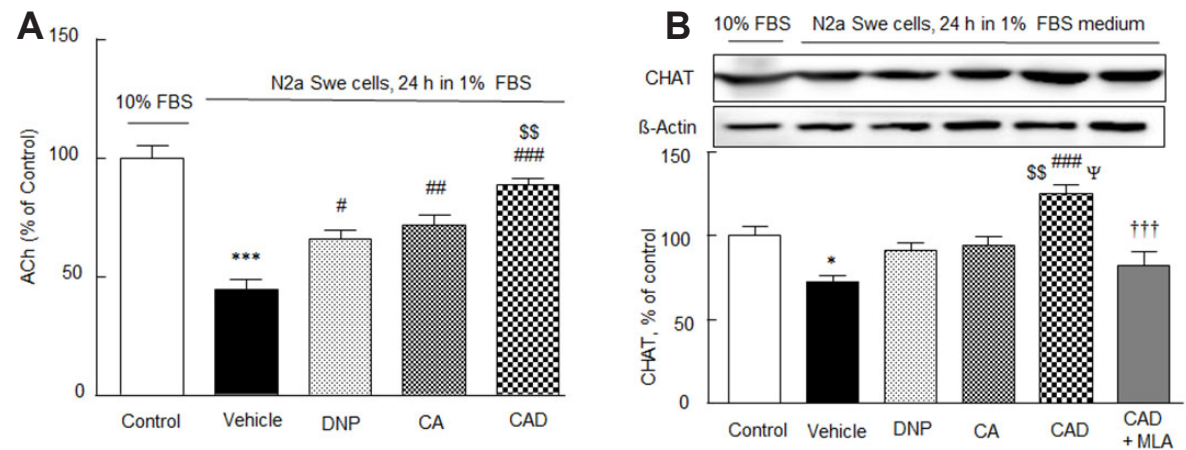

Fig. 6. Drug effects on acetylcholine (ACh) release and expression of choline acetyltransferase (CHAT) in the activated neuro2A (N2a) Swe cells. (A) Significant upregulation of decreased ACh release into the culture medium containing 1\% FBS with N2a Swe cells ( $24 \mathrm{~h}$ ) by $3 \mu \mathrm{M}$ donepezil (DNP), $3 \mu \mathrm{M}$ cilostazol $+3 \mu \mathrm{M}$ aripiprazole (CA) and CA + $3 \mu \mathrm{M}$ DNP (CAD). (B) Significant upregulation of CHAT expression by CAD, which was blocked by $10 \mathrm{nM}$ MLA (methyllycaconitine). Means \pm SEMs are expressed as percentages of control (ACh; $0.15 \pm 0.03 \mathrm{pg} / \mathrm{ml}=100 \%)$ of N2a Swe cells $(10 \%$ FBS) from 5 experiments. ${ }^{*} p<0.05,{ }^{* * *} p<0.001$ vs. control; ${ }^{\#} p<0.05,{ }^{\# \#} p<0.01,{ }^{\# \# \#} p<0.001$ vs. vehicle; ${ }^{\$ \$} p<0.01$ vs. DNP; ${ }^{\psi} p<0.05$ vs. CA; ${ }^{+t+1} p<0.001$ vs. CAD alone.

SIRT1 mRNA and protein expression in neurons. In the present study, CREB and P-CREB Ser133 expression was reduced by endogenously produced A $\beta$ in FBS-depleted medium in N2a Swe cells and that CAD synergistically reversed this decrease $\left(\mathrm{F}_{5,17}\right.$ $=13.09, p=0.0002)$ and this increased P-CREB Serl33 level by CAD was significantly depressed by LY294002 (PI3-kinase inhibitor) $\left(\mathrm{F}_{5,17}=13.09, \mathrm{p}=0.0002\right)$ (Fig. 5C).

\section{Reductions in acetylcholine release and CHAT expression in the activated N2a Swe cells and overcoming of this cholinergic disruption by CAD}

Solubilized amyloid $\beta$-peptide inhibits several steps of ACh synthesis/release and inhibits various cholinergic functions at nanomolar concentrations [43] and CHAT expression (a presyn- aptic marker) [44]. The ACh concentration released to cultured medium containing $10 \%$ FBS in the N2a Swe cells was $0.15 \pm 0.03$ $\mathrm{pg} / \mathrm{ml}$ (100\%) (Fig. 6A), and this was reduced to $45.2 \pm 4.0 \%$ (p < 0.001 ) in the activated N2a Swe cells. This decreased concentration was recovered by treatment with DNP (to $66.0 \pm 4.7 \%$, $\mathrm{p}<$ $0.05)$, $\mathrm{CA}(72.3 \pm 4.2 \%, \mathrm{p}<0.01)$ and by CAD $(89.5 \pm 2.8 \%, \mathrm{p}<$ 0.001 vs. vehicle; $\mathrm{p}<0.01$ vs. $\mathrm{DNP})\left(\mathrm{F}_{4,24}=25.14, \mathrm{p}<0.0001\right)$.

Similarly, CHAT expression was also significantly lowered to $72.2 \pm 3.8 \%(\mathrm{p}<0.05)$ in the activated N2a Swe cell group, and this reduction was moderately reversed by DNP or CA pretreatment, but significantly recovered over the control level by CAD (to $125.4 \pm 5.0 \% ; \mathrm{p}<0.001$ vs. vehicle; $\mathrm{p}<0.01$ vs. DNP; $\mathrm{p}<0.05$ vs. $\mathrm{CA})$. Furthermore, This CAD-stimulated CHAT expression was significantly blocked by $10 \mathrm{nM}$ methyllycaconitine (MLA) [45], (p $<0.001)\left(\mathrm{F}_{5,23}=10.45, \mathrm{p}<0.0001\right)$ (Fig. 6B). These results indicate 
CAD upregulated CHAT expression by activating $\alpha 7$-nicotinic cholinergic receptors in a synergistic manner.

\section{Neurite elongation}

Votin et al. [46] have reported that neuronal morphogenesis involves the formation and differentiation of neurites into axons and dendrites. In this study, we used HT22 cells, a murine cell line of hippocampal origin, expressing the BDNF receptor TrkB [47]. The neurite elongation of HT22 cells was analyzed under treatment with DNP alone, CA or CAD for 5 days following incubation with $3 \mu \mathrm{M}$ of $\mathrm{A} \beta_{1-42}$.

Neurites (control, $53.3 \pm 4.5 \mu \mathrm{m} ; \mathrm{n}=14$ ) showed significantly short length in $A \beta_{1-42}$ controls $(25.3 \pm 1.6 \mu \mathrm{m}, \mathrm{n}=17, \mathrm{p}<0.01)$, but neurite lengths were significantly increased in CA-pretreated cells $(65.9 \pm 4.2 \mu \mathrm{m}, \mathrm{n}=23, \mathrm{p}<0.001)$ and synergistically increased in CAD-pretreated cells $(130.0 \pm 12.6 \mu \mathrm{m}, \mathrm{n}=7, \mathrm{p}<0.001)$, but little in DNP-pretreated cells (Fig. 7A). These results strongly indicate that CAD significantly enhanced neurite elongation in HT22 cells.

We also evaluated whether increased neurite elongations induced by CAD were blocked by inhibitors. Increased neurite lengths $(130.0 \pm 12.6 \mu \mathrm{m})$ by CAD were significantly blocked by LY294002 (30 $\mu \mathrm{M})$ (a PI3K inhibitor) [47] to $45.7 \pm 4.8 \mu \mathrm{m}$ (p $<0.001, \mathrm{n}=22$ ), by K252A (100 nM; inhibitor of TrkB) [48] to
$41.0 \pm 3.6 \mu \mathrm{m}(\mathrm{p}<0.001, \mathrm{n}=24)$, by imatinib $(10 \mu \mathrm{M})(10 \mu \mathrm{M}, \mathrm{a}$ $\beta$-catenin inhibitor) [49] to $33.3 \pm 2.7 \mu \mathrm{m}(\mathrm{p}<0.001, \mathrm{n}=18)$, and by MLA (10 nM) (methyllycaconitine, a selective inhibitor of $\alpha 7$ nicotinic cholinergic receptor) [50] to $41.1 \pm 5.4 \mu \mathrm{m}$ ( $\mathrm{p}<0.001$, $\mathrm{n}=23)\left(\mathrm{F}_{8,160}=25.0, \mathrm{p}<0.0001\right)$ (Fig. 7B). These results suggest that activations of PI3K, BDNF, $\beta$-catenin, and $\alpha 7$-nicotinic cholinergic receptors are involved in the increase in neurite elongation induced by CAD in HT22 cells even in the presence of $3 \mu \mathrm{M}$ of $\mathrm{A} \beta_{1-42}$.

\section{Cell viability}

The cell viability of the activated N2a Swe cells was quantified by using a modified MTT reduction assay. N2a cells were pretreated with CAD $(3 \mu \mathrm{M}$ cilostazol $+3 \mu \mathrm{M}$ aripiprazole $+3 \mu \mathrm{M}$ donepezil) for $2 \mathrm{~h}$ before addition of $\mathrm{A} \beta_{1-42}(20 \mu \mathrm{M})$ and then cultured forward for $24 \mathrm{~h}$, after which the cell viability was assayed. Upon exposure of $\mathrm{N} 2 \mathrm{a}$ cells to $\mathrm{A} \beta_{1-42}(20 \mu \mathrm{M})$ for $24 \mathrm{~h}$ showed a significant decreased cell viability by $60 \pm 1.2 \%$ ( $p<0.001)$. The decreased viability induced by $\mathrm{A} \beta_{1-42}$ was significantly recovered by CAD to $80.5 \pm 5.0 \%(\mathrm{p}<0.05)$ at $24 \mathrm{~h}$, which was blocked by $30 \mu \mathrm{M}$ of LY294002 to $58 \pm 3.8 \%$ ( $\mathrm{p}<0.01), 100 \mathrm{nM}$ of K252A to $49.0 \pm 1.2 \%(\mathrm{p}<0.001)$, imatinib to $51 \pm 2.4 \%(\mathrm{p}<0.001)$ and 10 $\mathrm{nM}$ of MLA to $54 \pm 4.4 \%(\mathrm{p}<0.001)\left(\mathrm{F}_{6,35}=7, \mathrm{p}<0.0001\right)$ (Fig. 8). These results indicate that activations of PI3K, BDNF, $\beta$-catenin

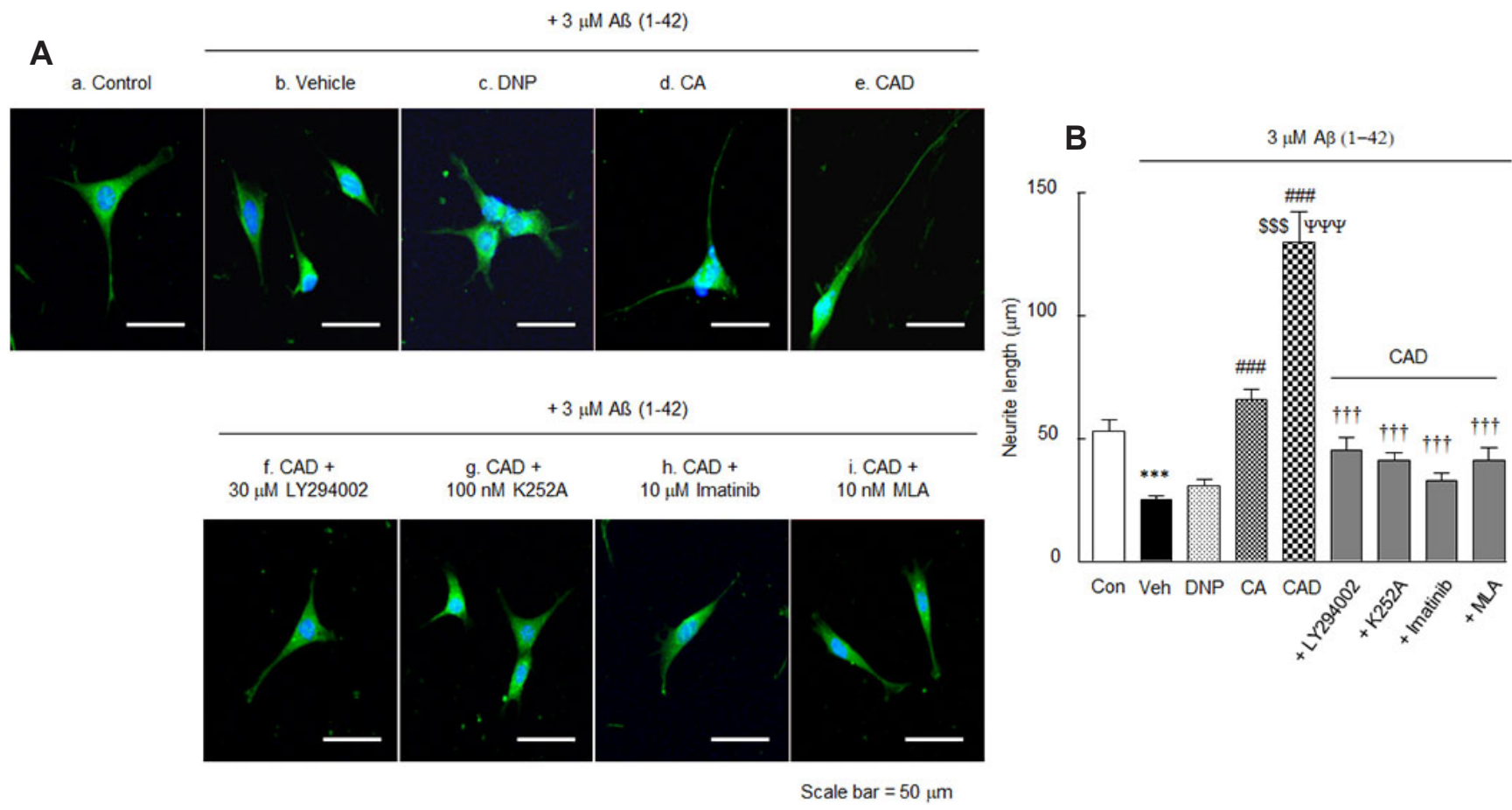

Fig. 7. Representative microscopic features (A) and their quantitative analyses (B). The neurite elongation of the HT22 cells was markedly decreased by $3 \mu \mathrm{M} \mathrm{A} \beta_{1-42}$, which was recovered over the control level by treatment with CA and synergistically increased by CAD, but not by $3 \mu \mathrm{m}$ donepezil (DNP) alone. Blocking of CAD-stimulated neurite lengths by LY294002 (30 $\mu$ M), K252A (100 nM), imatinib (10 $\mu$ M) and methyllycaconitine (MLA) $(10 \mathrm{nM})$, respectively. Results are expressed as means \pm SEMs of neurite length $(\mu \mathrm{m})$ in HT22 cells from 7-14 experiments. ${ }^{* * *} \mathrm{p}<0.001 \mathrm{vs}$. control (con); $\#$ \#\# $\mathrm{p} 0.001$ vs. vehicle (veh); ${ }^{\$ \$ \$} \mathrm{p}<0.001$ vs. DNP; ${ }^{\psi \psi \psi} \mathrm{p}<0.001$ vs. $\mathrm{CA} ;{ }^{+1+\dagger} \mathrm{p}<0.001$ vs. CAD alone. 


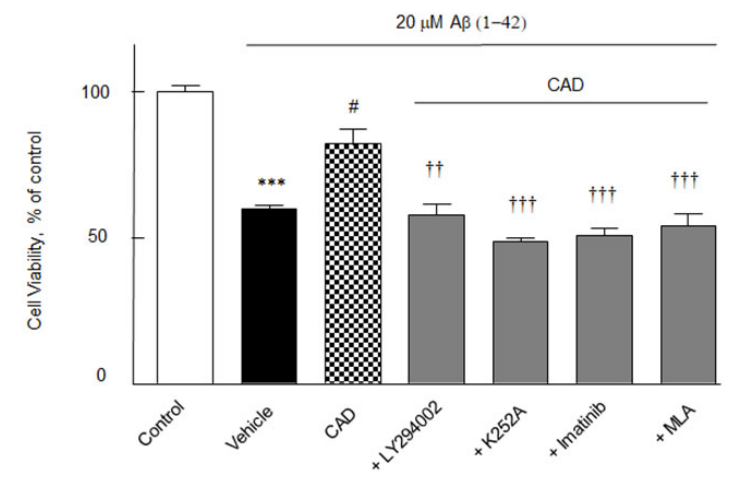

Fig. 8. Effects of drugs on the cell viability of neuro2A (N2a) cells. Cells were pretreated with CAD $(3 \mu \mathrm{M}$ donepezil $+3 \mu \mathrm{M}$ cilostazol + $3 \mu \mathrm{M}$ aripiprazole) for $2 \mathrm{~h}$ before addition of $A \beta_{1-42}(20 \mu \mathrm{M})$ and then cultured forward for $24 \mathrm{~h}$ in the absence and presence of $30 \mu \mathrm{M}$ of LY294002, $100 \mathrm{nM}$ of K252A, $10 \mu \mathrm{M}$ of imatinib and $10 \mathrm{nM}$ of methyllycaconitine (MLA), respectively. Results are expressed as means \pm SEMs of cell viability from 5 experiments. ${ }^{* * *} \mathrm{p}<0.001$ vs. control; ${ }^{*} \mathrm{p}<0.001$ vs. vehicle; ${ }^{+\dagger} \mathrm{p}<0.01,{ }^{\dagger+t} \mathrm{p}<0.001$ vs. CAD alone.

and $\alpha 7$-nicotinic cholinergic receptors are importantly involved in the increase in cell viability by $\mathrm{CAD}$ even in the presence of 3 $\mu \mathrm{M}$ of $\mathrm{A} \beta_{1-42}$.

\section{DISCUSSION}

The present study links upregulation of SIRT1 expression/activity with P-CREB Ser 133 induced by combination therapy with $3 \mu \mathrm{M}$ cilostazol $+3 \mu \mathrm{M}$ aripiprazole and $3 \mu \mathrm{M}$ of donepezil addon (CAD) to blockade of $\beta$-amyloid production (amyloid hypothesis), to inhibition of Ac-tau and P-tau (tau hypothesis) via inhibition of P300 and GSK-3 $\beta$, and to upregulation of $\alpha$-secretase/ ADAM10 in the activated N2a Swe cells overproducing A $\beta$. In addition, $\mathrm{CAD}$ synergistically upregulated $\mathrm{ACh}$ release and CHAT expression in the activated N2a Swe cells. Consequently, CAD treatment synergistically increased neurite elongation and improved cell viability in the presence of $A \beta_{1-42}$ via activations of PI3K, BDNF, $\beta$-catenin, and $\alpha 7$-nicotinic cholinergic receptors in neuronal cells.

A cholinergic hypothesis has been proposed based on the premise that cholinergic agents are a logical choice for preventative AD therapy $[13,44]$. Nevertheless, single treatment with cholinesterase inhibitors cannot overcome the multifactorial pathologies of AD. Accordingly, we proposed that lower doses of cilostazol plus aripiprazole therapy with add-on donepezil may ensure a superior therapeutic window for the long-term treatment of $\mathrm{AD}$ with fewer side effects. In the current study, we identified that $C A D$ exerts synergistic inhibition on the multi-pathogenic factors: A $\beta$ accumulation, P300, Ac-tau, GSK-3 $\beta$, P-tau by synergistic upregulation of $\alpha$-secretase/ADAM10 and SIRT1, neuronal ACh content, and CHAT expression.

Tau is acetylated by histone acetyltransferase in the presence of excessive $A \beta$ accumulation [38]. $A \beta$ aggregate has been reported to activate $\mathrm{p} 300$ (a $300 \mathrm{kDa}$ protein), which has acetyltransferase activity, and thus, $A \beta$ increases Ac-tau production and tauopathies [39]. In addition, it was reported that phosphorylation of GSK-3 $\beta$ at Tyr 216 increases GSK-3 $\beta$ activity in neuronal cells and degenerate cortical neurons and this activation causes hyperphosphorylation of tau $[36,37]$. We observed that $A \beta$ accumulation in the activated N2a Swe cells was not suppressed by $3 \mu \mathrm{M}$ donepezil alone but by $\mathrm{CA}(\mathrm{p}<0.01)$ and CAD $(\mathrm{p}<0.001)$. Furthermore, increases in expressions of P300 and GSK-3 $\beta$ P-Tyr216 were not inhibited by $3 \mu \mathrm{M}$ donepezil or CA but were significantly inhibited by CAD. Consequently, CAD synergistically inhibited P-tau and Ac-tau levels, indicating CAD treatment synergistically inhibit $\beta$ amyloid accumulation.

A question arises as to the mechanism by which cilostazol elevates SIRT1 expression and activity. Transcription factor CREB was reported to act as a regulator of neuronal differentiation and plasticity [51]. SIRT1 expression is transcriptionally activated by CREB in HepG2 cells stimulated with forskolin [52]. Fusco et al. [42] proposed that effects of calorie restriction on neuronal plasticity and memory are abolished in mice lacking CREB-1 in forebrain and found CREB deficiency drastically reduced SIRT-1 expression. Overall, these results indicate CREB regulates SIRT-1 mRNA and protein expression in neurons. Lee et al. [35] reported that endogenous $A \beta$ overproduction in the N2a Swe cells downregulated P-CREB Ser133 time-dependently and expression of SIRT1 mRNA and its activity. In the current study, following pretreatment with cilostazol, increase in P-CREB Ser133 level was accompanied by elevated SIRT1 mRNA expression accordingly. Consistent with this report, SIRT1 expression and its deacetylase activity was significantly upregulated by CAD in a synergistic manner, whereas either $3 \mu \mathrm{M}$ of donepezil or $3 \mu \mathrm{M}$ cilostazol +3 $\mu \mathrm{M}$ aripiprazole (CA) had only marginal changes. Furthermore, pretreatment with sirtinol (an SIRT1 inhibitor) significantly inhibited these protective effects of CAD.

On the other hand, Park et al. [29] showed that aripiprazole exhibited preventive effects against $A \beta$-induced neurotoxicity. They demonstrated aripiprazole decreased BDNF and P-CK2 $\alpha$ expression induced by $A \beta_{1-42}$ were markedly recovered in the $\mathrm{N} 2 \mathrm{a}$ cells. In addition, $A \beta_{1-42}$-induced decreased levels of P-GSK-3 $\beta$ at Ser9 and nuclear P- $\beta$-catenin at Ser675 were also recovered by aripiprazole. These results suggest that aripiprazole and cilostazol share some common pharmacological actions for interplay.

Donepezil (AChE inhibitor) elevates ACh levels by inhibiting ACh hydrolysis in the synaptic clefts, and thus, increases cholinergic transmission [53]. In addition, these neuroprotective effects have been ascribed to activation of nicotinic acetylcholine receptors (nAChRs), PI3K/Akt pathway and upregulation of antiapoptotic Bcl-2 [54-56]. Consistent with these reports, CAD-stimulated CHAT expression in the present study was significantly blocked by MLA (methyllycaconitine, a selective inhibitor of $\alpha 7$ nicotinic cholinergic receptor) [50]. 
Zimmermann et al. [57] reported that in differentiated human neuroblastoma cells (SH-SY5Y), sAPP $\alpha$ was released into the medium and ADAM10 level was increased in the membrane compartments after donepezil treatment. Postina et al. [3] reported $\mathrm{A} \beta$ peptide production is reduced by activating $\alpha$-secretase. Qin et al. [15] observed activation of mammalian SIRT1 was positively associated with $\alpha$-secretase activity in vivo, and Lee et al. [19] revealed cilostazol suppresses accumulations of full length$\mathrm{APP}$ and $\mathrm{A} \beta$ production by increasing ADAM 10 and $\alpha$-secretase activities via SIRT1-coupled RAR $\beta$ in N2a Swe cells. In line with these results, we observed SIRT1 protein expression and SIRT1 deacetylase activity were significantly and synergistically upregulated by CAD in the activated N2a Swe cells, but these were marginally increased by DNP or CA. Furthermore, these increases in SIRT1 levels in activated cells were wholly blocked by sirtinol (a SIRT1 inhibitor). Despite the observed lack of efficacy of DNP and CA, the facts that CAD upregulated SIRT1 expression and activity reflects sharing of pharmacological interplay, because DNP has been reported to upregulate SIRT1 protein expression in hippocampi and cortices in senescence-accelerated mouse prone 8 (SAMP8) [58].

In the present study, HT22 cells, mouse hippocampal neuronal cell line, were used instead of N2a cells, because HT22 cells phenotypically resemble neuronal precursor cells expressing BDNF receptor $\operatorname{TrkB}$, and it lacks functional ionotropic glutamate receptors [47]. Thus, it can exclude neurite outgrowth damage by excitotoxicity caused by glutamate other than $A \beta_{1-42}$. Neurite length which was markedly decreased in the presence of $A \beta_{1-42}$ was significantly recovered by treatment with CAD in larger degree, indicating CAD synergistically increased neurite elongation in HT22 cells. Furthermore, CAD significantly protected N2a cells from $A \beta_{1-42}$-induced cell death. These observations are supported by our previous findings that cilostazol prevented $A \beta$ induced HT22 apoptosis by downregulating phosphorylated p53 (Ser 15), Bax, and caspase-3 levels, upregulating Bcl-2 levels, and preventing $A \beta$-induced neurite shortening and decreased cell viability [35]. Furthermore, these protective effects of CAD on neurite shortening and cell death were significantly blocked by LY294002, K252A (an inhibitor of BDNF receptor), imatinib ( $\beta$-catenin inhibitor), and MLA (methyllycaconitine; a selective inhibitor of $\alpha$ 7-nicotinic cholinergic receptor), suggesting that activations of PI3K, BDNF, $\beta$-catenin, and $\alpha 7$-nicotinic cholinergic receptors are importantly implicated in the protective effects of $\mathrm{CAD}$ on $\mathrm{A} \beta$-induced neurite shortening.

Taken together, the present study shows multitarget-faceted combinatorial drug therapies are worthy of investigation in the contexts of preventing and treating $\mathrm{AD}$, and our results endorse a shift to multitarget -directed therapeutic approaches. In addition, these results support the notion that low dose cilostazol plus aripiprazole with add-on donepezil offers a wider therapeutic window for the long-term treatment of $\mathrm{AD}$.

\section{ACKNOWLEDGEMENTS}

This study was supported by a 2-Year Research Grant of Pusan National University, Republic of Korea.

\section{CONFLICTS OF INTEREST}

The authors declare no conflicts of interest.

\section{REFERENCES}

1. Lue LF, Kuo YM, Roher AE, Brachova L, Shen Y, Sue L, Beach T, Kurth JH, Rydel RE, Rogers J. Soluble amyloid beta peptide concentration as a predictor of synaptic change in Alzheimer's disease. Am J Pathol. 1999;155:853-862.

2. Nunan J, Small DH. Regulation of APP cleavage by alpha-, beta- and gamma-secretases. FEBS Lett. 2000;483:6-10.

3. Postina R, Schroeder A, Dewachter I, Bohl J, Schmitt U, Kojro E, Prinzen C, Endres K, Hiemke C, Blessing M, Flamez P, Dequenne A, Godaux E, van Leuven F, Fahrenholz F. A disintegrin-metalloproteinase prevents amyloid plaque formation and hippocampal defects in an Alzheimer disease mouse model. J Clin Invest. 2004;113:14561464.

4. Kojro E, Fahrenholz F. The non-amyloidogenic pathway: structure and function of alpha-secretases. Subcell Biochem. 2005;38:105-127.

5. Rojo AI, Sagarra MR, Cuadrado A. GSK-3beta down-regulates the transcription factor Nrf2 after oxidant damage: relevance to exposure of neuronal cells to oxidative stress. J Neurochem. 2008; 105:192-202.

6. Ballatore C, Lee VM, Trojanowski JQ. Tau-mediated neurodegeneration in Alzheimer's disease and related disorders. Nat Rev Neurosci. 2007;8:663-672.

7. Hooper C, Killick R, Lovestone S. The GSK3 hypothesis of Alzheimer's disease. J Neurochem. 2008;104:1433-1439.

8. Jämsä A, Hasslund K, Cowburn RF, Bäckström A, Vasänge M. The retinoic acid and brain-derived neurotrophic factor differentiated SH-SY5Y cell line as a model for Alzheimer's disease-like tau phosphorylation. Biochem Biophys Res Commun. 2004;319:993-1000.

9. Lee HR, Park SY, Kim HY, Shin HK, Lee WS, Rhim BY, Hong KW, Kim CD. Protection by cilostazol against amyloid- $\beta 1-40$-induced suppression of viability and neurite elongation through activation of CK $2 \alpha$ in HT22 mouse hippocampal cells. J Neurosci Res. 2012;90:1566-1576.

10. Counts SE, Mufson EJ. The role of nerve growth factor receptors in cholinergic basal forebrain degeneration in prodromal Alzheimer disease. J Neuropathol Exp Neurol. 2005;64:263-272.

11. Niewiadomska G, Baksalerska-Pazera M, Riedel G. The septohippocampal system, learning and recovery of function. Prog Neuropsychopharmacol Biol Psychiatry. 2009;33:791-805.

12. Francis PT, Palmer AM, Snape M, Wilcock GK. The cholinergic hypothesis of Alzheimer's disease: a review of progress. J Neurol Neurosurg Psychiatry. 1999;66:137-147.

13. Sanabria-Castro A, Alvarado-Echeverría I, Monge-Bonilla C. Molecular pathogenesis of Alzheimer's disease: an update. Ann Neuro- 
sci. 2017;24:46-54.

14. Anekonda TS, Reddy PH. Neuronal protection by sirtuins in Alzheimer's disease. J Neurochem. 2006;96:305-313.

15. Qin W, Yang T, Ho L, Zhao Z, Wang J, Chen L, Zhao W, Thiyagarajan M, MacGrogan D, Rodgers JT, Puigserver P, Sadoshima J, Deng H, Pedrini S, Gandy S, Sauve AA, Pasinetti GM. Neuronal SIRT1 activation as a novel mechanism underlying the prevention of Alzheimer disease amyloid neuropathology by calorie restriction. $J$ Biol Chem. 2006;281:21745-21754.

16. Michán S, Li Y, Chou MM, Parrella E, Ge H, Long JM, Allard JS, Lewis K, Miller M, Xu W, Mervis RF, Chen J, Guerin KI, Smith LE, McBurney MW, Sinclair DA, Baudry M, de Cabo R, Longo VD. SIRT1 is essential for normal cognitive function and synaptic plasticity. J Neurosci. 2010;30:9695-9707.

17. Julien C, Tremblay C, Emond V, Lebbadi M, Salem N Jr, Bennett DA, Calon F. Sirtuin 1 reduction parallels the accumulation of tau in Alzheimer disease. J Neuropathol Exp Neurol. 2009;68:48-58.

18. Tippmann F, Hundt J, Schneider A, Endres K, Fahrenholz F. Upregulation of the alpha-secretase ADAM10 by retinoic acid receptors and acitretin. FASEB J. 2009;23:1643-1654.

19. Lee HR, Shin HK, Park SY, Kim HY, Lee WS, Rhim BY, Hong KW, Kim CD. Cilostazol suppresses $\beta$-amyloid production by activating a disintegrin and metalloproteinase 10 via the upregulation of SIRT1coupled retinoic acid receptor- $\beta$. J Neurosci Res. 2014;92:1581-1590.

20. Lee JH, Kim KY, Lee YK, Park SY, Kim CD, Lee WS, Rhim BY, Hong KW. Cilostazol prevents focal cerebral ischemic injury by enhancing casein kinase 2 phosphorylation and suppression of phosphatase and tensin homolog deleted from chromosome 10 phosphorylation in rats. J Pharmacol Exp Ther. 2004;308:896-903.

21. Hong KW, Lee JH, Kima KY, Park SY, Lee WS. Cilostazol: therapeutic potential against focal cerebral ischemic damage. Curr Pharm Des. 2006;12:565-573.

22. Park SH, Kim JH, Bae SS, Hong KW, Lee DS, Leem JY, Choi BT, Shin HK. Protective effect of the phosphodiesterase III inhibitor cilostazol on amyloid $\beta$-induced cognitive deficits associated with decreased amyloid $\beta$ accumulation. Biochem Biophys Res Commun. 2011;408:602-608.

23. Burris KD, Molski TF, Xu C, Ryan E, Tottori K, Kikuchi T, Yocca FD, Molinoff PB. Aripiprazole, a novel antipsychotic, is a highaffinity partial agonist at human dopamine D2 receptors. J Pharmacol Exp Ther. 2002;302:381-389.

24. Croxtall JD. Aripiprazole: a review of its use in the management of schizophrenia in adults. CNS Drugs. 2012;26:155-183.

25. Pae CU, Forbes A, Patkar AA. Aripiprazole as adjunctive therapy for patients with major depressive disorder: overview and implications of clinical trial data. CNS Drugs. 2011;25:109-127.

26. Paulsen JS, Salmon DP, Thal LJ, Romero R, Weisstein-Jenkins C, Galasko D, Hofstetter CR, Thomas R, Grant I, Jeste DV. Incidence of and risk factors for hallucinations and delusions in patients with probable AD. Neurology. 2000;54:1965-1971.

27. Eustace A, Coen R, Walsh C, Cunningham CJ, Walsh JB, Coakley D, Lawlor BA. A longitudinal evaluation of behavioural and psychological symptoms of probable Alzheimer's disease. Int J Geriatr Psychiatry. 2002;17:968-973.

28. De Deyn P, Jeste DV, Swanink R, Kostic D, Breder C, Carson WH, Iwamoto T. Aripiprazole for the treatment of psychosis in patients with Alzheimer's disease: a randomized, placebo-controlled study. J
Clin Psychopharmacol. 2005;25:463-467.

29. Park SY, Shin HK, Lee WS, Bae SS, Kim K, Hong KW, Kim CD. Neuroprotection by aripiprazole against $\beta$-amyloid-induced toxicity by P-CK $2 \alpha$ activation via inhibition of GSK-3 $\beta$. Oncotarget. 2017;8:110380-110391.

30. Guzior N, Wieckowska A, Panek D, Malawska B. Recent development of multifunctional agents as potential drug candidates for the treatment of Alzheimer's disease. Curr Med Chem. 2015;22:373404.

31. Whitehouse PJ, Price DL, Struble RG, Clark AW, Coyle JT, Delon MR. Alzheimer's disease and senile dementia: loss of neurons in the basal forebrain. Science. 1982;215:1237-1239.

32. Takada-Takatori Y, Kume T, Izumi Y, Ohgi Y, Niidome T, Fujii T, Sugimoto H, Akaike A. Roles of nicotinic receptors in acetylcholinesterase inhibitor-induced neuroprotection and nicotinic receptor up-regulation. Biol Pharm Bull. 2009;32:318-324.

33. Sugimoto H, Yamanishi Y, Iimura Y, Kawakami Y. Donepezil hydrochloride (E2020) and other acetylcholinesterase inhibitors. Curr Med Chem. 2000;7:303-339.

34. Giacobini E. Cholinesterase inhibitors stabilize Alzheimer's disease. Ann N Y Acad Sci. 2000;920:321-327.

35. Lee HR, Shin HK, Park SY, Kim HY, Lee WS, Rhim BY, Hong $\mathrm{KW}$, Kim CD. Attenuation of $\beta$-amyloid-induced tauopathy via activation of CK $2 \alpha /$ SIRT1: targeting for cilostazol. J Neurosci Res. 2014;92:206-217.

36. Leroy K, Yilmaz Z, Brion JP. Increased level of active GSK-3beta in Alzheimer's disease and accumulation in argyrophilic grains and in neurones at different stages of neurofibrillary degeneration. Neuropathol Appl Neurobiol. 2007;33:43-55.

37. Hoshi M, Sato M, Matsumoto S, Noguchi A, Yasutake K, Yoshida N, Sato K. Spherical aggregates of beta-amyloid (amylospheroid) show high neurotoxicity and activate tau protein kinase I/glycogen synthase kinase-3beta. Proc Natl Acad Sci U S A. 2003;100:6370-6375.

38. Bannister AJ, Kouzarides T. The CBP co-activator is a histone acetyltransferase. Nature. 1996;384:641-643.

39. Min SW, Cho SH, Zhou Y, Schroeder S, Haroutunian V, Seeley WW, Huang EJ, Shen Y, Masliah E, Mukherjee C, Meyers D, Cole PA, Ott M, Gan L. Acetylation of tau inhibits its degradation and contributes to tauopathy. Neuron. 2010;67:953-966.

40. Amour A, Knight CG, Webster A, Slocombe PM, Stephens PE, Knäuper V, Docherty AJ, Murphy G. The in vitro activity of ADAM10 is inhibited by TIMP-1 and TIMP-3. FEBS Lett. 2000;473:275279.

41. Araki T, Sasaki Y, Milbrandt J. Increased nuclear NAD biosynthesis and SIRT1 activation prevent axonal degeneration. Science. 2004;305:1010-1013.

42. Fusco S, Ripoli C, Podda MV, Ranieri SC, Leone L, Toietta G, McBurney MW, Schütz G, Riccio A, Grassi C, Galeotti T, Pani G. A role for neuronal cAMP responsive-element binding (CREB)-1 in brain responses to calorie restriction. Proc Natl Acad Sci U S A. 2012;109:621-626.

43. Auld DS, Kar S, Quirion R. Beta-amyloid peptides as direct cholinergic neuromodulators: a missing link? Trends Neurosci. 1998; 21:43-49.

44. Potter PE, Rauschkolb PK, Pandya Y, Sue LI, Sabbagh MN, Walker DG, Beach TG. Pre- and post-synaptic cortical cholinergic deficits are proportional to amyloid plaque presence and density at preclini- 
cal stages of Alzheimer's disease. Acta Neuropathol. 2011;122:49-60.

45. Takada-Takatori Y, Kume T, Ohgi Y, Fujii T, Niidome T, Sugimoto H, Akaike A. Mechanisms of alpha7-nicotinic receptor up-regulation and sensitization to donepezil induced by chronic donepezil treatment. Eur J Pharmacol. 2008;590:150-156.

46. Votin V, Nelson WJ, Barth AI. Neurite outgrowth involves adenomatous polyposis coli protein and beta-catenin. J Cell Sci. 2005; 118(Pt 24):5699-5708.

47. Rössler OG, Giehl KM, Thiel G. Neuroprotection of immortalized hippocampal neurones by brain-derived neurotrophic factor and Raf-1 protein kinase: role of extracellular signal-regulated protein kinase and phosphatidylinositol 3-kinase. J Neurochem. 2004;88:1240-1252.

48. Tapley P, Lamballe F, Barbacid M. K252a is a selective inhibitor of the tyrosine protein kinase activity of the trk family of oncogenes and neurotrophin receptors. Oncogene. 1992;7:371-381.

49. Torii K, Nishizawa K, Kawasaki A, Yamashita Y, Katada M, Ito M, Nishimoto I, Terashita K, Aiso S, Matsuoka M. Anti-apoptotic action of Wnt5a in dermal fibroblasts is mediated by the PKA signaling pathways. Cell Signal. 2008;20:1256-1266.

50. Takada-Takatori Y, Kume T, Ohgi Y, Fujii T, Niidome T, Sugimoto H, Akaike A. Mechanisms of alpha7-nicotinic receptor up-regulation and sensitization to donepezil induced by chronic donepezil treatment. Eur J Pharmacol. 2008;590:150-156.

51. Mantamadiotis T, Lemberger T, Bleckmann SC, Kern H, Kretz O, Martin Villalba A, Tronche F, Kellendonk C, Gau D, Kapfhammer J, Otto C, Schmid W, Schütz G. Disruption of CREB function in brain leads to neurodegeneration. Nat Genet. 2002;31:47-54.

52. Noriega LG, Feige JN, Canto C, Yamamoto H, Yu J, Herman MA, Mataki C, Kahn BB, Auwerx J. CREB and ChREBP oppositely regulate SIRT1 expression in response to energy availability. EMBO Rep. 2011;12:1069-1076.

53. Kosasa T, Kuriya Y, Matsui K, Yamanishi Y. Effect of donepezil hydrochloride (E2020) on basal concentration of extracellular acetylcholine in the hippocampus of rats. Eur J Pharmacol. 1999;380:101107.

54. Kihara T, Shimohama S, Sawada H, Kimura J, Kume T, Kochiyama H, Maeda T, Akaike A. Nicotinic receptor stimulation protects neurons against beta-amyloid toxicity. Ann Neurol. 1997;42:159-163.

55. Hashimoto M, Kazui H, Matsumoto K, Nakano Y, Yasuda M, Mori E. Does donepezil treatment slow the progression of hippocampal atrophy in patients with Alzheimer's disease? Am J Psychiatry. 2005;162:676-682.

56. Kimura M, Akasofu S, Ogura H, Sawada K. Protective effect of donepezil against Abeta(1-40) neurotoxicity in rat septal neurons. Brain Res. 2005;1047:72-84.

57. Zimmermann M, Gardoni F, Marcello E, Colciaghi F, Borroni B, Padovani A, Cattabeni F, Di Luca M. Acetylcholinesterase inhibitors increase ADAM10 activity by promoting its trafficking in neuroblastoma cell lines. J Neurochem. 2004;90:1489-1499.

58. Zhang SJ, Xu TT, Li L, Xu YM, Qu ZL, Wang XC, Huang SQ, Luo Y, Luo NC, Lu P, Shi YF, Yang X, Wang Q. Bushen-Yizhi formula ameliorates cognitive dysfunction through SIRT1/ER stress pathway in SAMP8 mice. Oncotarget. 2017;8:49338-49350. 